Original Research Article

\title{
Efficacy of Erythropoietin in treatment of anemia in patients hospitalized in the ICU of Ardabil city hospital
}

\author{
Iraj Feizi ${ }^{1}$, Vadood Norouzi ${ }^{2 *}$
}

${ }^{1}$ Department of Surgery, ${ }^{2}$ Department of Anaesthesia, Faculty of Medicine, Ardabil University of Medical Science, Ardabil, Iran

Received: 26 June 2018 Accepted: 26 July 2018

\section{*Correspondence to:}

Dr. Vadood Norouzi,

Email: v.nourouzi@arums.ac.ir

Copyright: (C) the author(s), publisher and licensee Medip Academy. This is an openaccess article distributed under the terms of the Creative Commons Attribution NonCommercial License, which permits unrestricted noncommercial use, distribution, and reproduction in any medium, provided the original work is properly cited.

\begin{abstract}
Background: Several studies have shown that approximately $95 \%$ of patients who have been admitted to the ICU are anemic. Anemia in acute patients leads to significant transfusion. Transfusion can lead to significant complications. Because of the risks of transfusion an alternative therapy for anemia in patients seems be a necessary need for its. The aim of this study was to investigate the efficacy of Erythropoietin in treatment of anemia in patients hospitalized in the ICU of Ardabil city hospital.

Methods: This study is a clinical trial. In this study after selection of patients based on inclusion and exclusion criteria, their data were entered in a check list. Patients were divided into two groups of 35 persons randomly. For first group, erythropoietin was administrated in addition of iron and in second group only iron was administrated. All patients were administrated $100 \mathrm{mg}$ of iron. Hematological indexes and clinical status of patients was evaluated and results were analyzed by statistical methods in SPSS version 19.

Results: In this study, in cases $65.7 \%$ and in controls $71.4 \%$ were male. The average age of patients in cases was $61.6 \pm 20.8$ and controls were $61.02 \pm 22.5$ years. The mean duration of hospitalization in internal ICU was 37.73 days and in surgical ICU was 21.35 days and was observed that at baseline the hemoglobin levels in internal patients was lower than surgical patients $(p=0.023) .80 \%$ of patients in case group (5.8 units) and $88.57 \%$ of patients in controls (6.3 units) required blood transfusion. The hemoglobin level in erythropoietin receiving group increased significantly compared to the control group.

Conclusions: The results of this study showed that erythropoietin is an effective drug to increase hemoglobin level and can provide a significant increase in hemoglobin level compared to placebo.
\end{abstract}

Keywords: Anemia, Erythropoietin, Intensive Care Unit

\section{INTRODUCTION}

Anemia define as a reduction in red blood cell mass, hemoglobin $(\mathrm{Hb})<12 \mathrm{~g} / \mathrm{dL}$ and hematocrit less than $36 \%$ in women and $\mathrm{Hb}<14 \mathrm{~g} / \mathrm{dL}$ and hematocrit less than $41 \%$ in men and its clinical manifestations vary according to etiology, severity and starting speed. Other disorders such as cardiopulmonary diseases may be effective in the severity of anemia symptoms. Severe anemia can be tolerated if it is gradually developed, but usually patients with $\mathrm{Hb}<7 \mathrm{~g} / \mathrm{dL}$ show hypoxic tissue symptoms such as fatigue, headache, asthma, light-headedness and angina. Wannes, visual disturbance, Syncop and tachycardia may be an indication of hypovolemic anemia that needs to immediate attention.

According to Prakash idea in 2012, anemia was common in the intensive care unit (ICU) and increases morbidity and mortality; its etiology is multi-factorial but anemia due to inflammation is the most important cause and is exactly like anemia of iron deficiency. Transfusion and the use of erythropoietin are two methods that are used to correct anemia in sick patients. ${ }^{2}$ A great part of these patients have 
anemia during hospitalization and a great part of them undergoing anemia during their stay in the ICU that anemia increases with the duration of hospitalization in the ICU. Sekhon and et al, stated that the average of $\mathrm{Hb}$ on day seventh is less than $9 \mathrm{~g} / \mathrm{dL}$ in hospitalized patients with severe brain trauma which admitted to ICU with high mortality risk. ${ }^{3}$ In various studies it has been shown that 95\% of patients suffered to anemia in the third day of hospitalization in ICU. ${ }^{4}$ This event may be due to the fact that patients with severe illness who need to be admitted to the ICU, in $90 \%$ of cases it has low of iron and total connection capacity (TIBC) and had normal or slightly higher than normal ferritin. ${ }^{5-6}$

Herbert and et al in a study showed that the effect of maintaining $\mathrm{Hb}$ in ICU patients at $8-9 \mathrm{~g} / \mathrm{dL}$ is at least equal to the effect of maintaining this level at $10 \mathrm{~g} / \mathrm{dL}$ by helping transfusion. Also, transfusion to be widely used for anemia patients. $^{7} 50 \%$ of all anemia patients during their hospitalization in the ICU and $85 \%$ of patients with more than one week hospitalization in ICU undergoing blood transfusion at least once. ${ }^{8-9}$ Transfusion is not a safe process and can have many problems including infection, immune response, pulmonary edema and pulmonary injury to the recipient, especially when this person has other problems that led to his hospitalization in the ICU. ${ }^{10,11}$ Due to the dangers of transfusion, there is emergency need for alternative treatment for anemia in severe patients. Erythropoietin treatment in severe patients increases erythropoietin and results in high levels of hemoglobin and finally reduced transfusion. ${ }^{12-15}$ The aim of this study was to evaluate the efficacy of erythropoietin in the treatment of anemia in ICU patients in Ardabil.

\section{METHODS}

This is a clinical trial study conducted at ICU in Ardabil hospitals. A total of 70 patients hospitalized in the ICU were selected and randomly divided into two similar groups. To the first group in addition to iron, erythropoietin was also prescribed, and only iron was given to the second group (control group). 100mg iron was prescribed for all patients. For the case group in the state of a decrease in $\mathrm{Hb}$ levels less than $12 \mathrm{~g} / \mathrm{dL}$ for three times 40,000 units of erythropoietin were injected weekly. In the case of hemoglobin less than $8 \mathrm{mg} / \mathrm{dL}$ in non-cardiac patients and hemoglobin less than $10 \mathrm{mg} / \mathrm{dL}$ in patients with heart disease (ischemic) blood were also prescribed for patients. At the end of study, blood indices and clinical status of the patient were evaluated at the end of the study. Required information including demographic information, cause and duration of hospitalization in ICU, history of transfusion, cause of need for blood transfusion, time and dose of receiving erythropoietin, blood parameters before and after receiving erythropoietin and patient's clinical condition after receiving erythropoietin was extracted through a checklist. Data were analyzed by statistical methods in SPSS version 19. In all tests the level of significance was less than 0.05 .

\section{Inclusion and exclusion criteria}

Patients aged 18 years and above, Hematocrit less than $38 \%$ and hospitalization in ICU for more than 7 days were enrolled in the study. Patients with uncontrolled hypertension, uncontrolled seizures, burn grade 3 and higher, pregnancy or lactation, dialysis patients, pulmonary embolism, DVT and chronic hypercoagulopathy were excluded from the study. The study was conducted after approval at the university's ethics committee.

\section{RESULTS}

In this study, $65.7 \%$ of the case group and $71.4 \%$ of the control group were male and the rest of them were female. The mean age of the patients in the case group was $61.62 \pm 20.8$ and in the control group was $61.02 \pm 22.5$ years (Table 1).

Table 1: Clinical characteristics of patients in two study group.

\begin{tabular}{|c|c|c|c|c|c|}
\hline \multirow{2}{*}{\multicolumn{2}{|c|}{$\begin{array}{l}\text { Groups } \\
\text { Variables }\end{array}$}} & \multicolumn{2}{|c|}{ Case } & \multicolumn{2}{|c|}{ Control } \\
\hline & & $\mathbf{n}$ & $\%$ & $\mathbf{n}$ & $\%$ \\
\hline \multirow{2}{*}{$\operatorname{sex}$} & $\mathrm{m}$ & 23 & 65.7 & 25 & 71.4 \\
\hline & $\mathrm{f}$ & 12 & 34.3 & 10 & 28.6 \\
\hline \multirow{2}{*}{ Age } & $>70$ & 19 & 54.3 & 17 & 48.6 \\
\hline & $<=70$ & 16 & 45.7 & 18 & 51.4 \\
\hline \multicolumn{2}{|l|}{ Mean of age } & \multicolumn{2}{|c|}{$61.62 \pm 20.8$} & \multicolumn{2}{|c|}{$61.02 \pm 22.5$} \\
\hline \multicolumn{2}{|l|}{$\begin{array}{l}\text { Mean of } \\
\text { hospitalization }\end{array}$} & \multicolumn{2}{|c|}{$32.2 \pm 21.7$} & \multicolumn{2}{|c|}{$30.2 \pm 21.5$} \\
\hline \multirow{2}{*}{$\mathrm{RH}+$} & + & 29 & 82.9 & 27 & 77.1 \\
\hline & - & 6 & 17.1 & 8 & 22.9 \\
\hline \multirow{2}{*}{$\begin{array}{l}\text { History of } \\
\text { heart disease }\end{array}$} & + & 24 & 68.6 & 21 & 60 \\
\hline & - & 11 & 31.4 & 14 & 40 \\
\hline \multirow{2}{*}{ Blood type o } & + & 14 & 40 & 15 & 42.9 \\
\hline & - & 21 & 60 & 20 & 57.1 \\
\hline \multirow{2}{*}{$\begin{array}{l}\text { History of } \\
\text { transfusion }\end{array}$} & + & 9 & 25.7 & 7 & 20 \\
\hline & - & 26 & 74.3 & 28 & 80 \\
\hline \multirow{2}{*}{$\begin{array}{l}\text { Need for } \\
\text { transfusion }\end{array}$} & + & 28 & 80 & 31 & 88.6 \\
\hline & - & 7 & 20 & 4 & 11.4 \\
\hline
\end{tabular}

The mean of injected blood in patients receiving blood in the case group was $5.8 \pm 1.8$ and $6.3 \pm 2.9$ in the control group. 13 patients in the case group were between 3 to 6 units and 15 patients in the control group received 7-9 blood units. The most common cause of blood transfusion was acute anemia in both groups. In the case group, 24 patients $(68.6 \%)$ and in the control group, 25 patients $(71.4 \%)$ survived until the ICU discharged and the end of the study. In term of complications of erythropoietin injection, we observed that none of the patients in the case group hadn't complications. The results showed no significant difference in the experimental results of the patients at the beginning of the study (Table 2). 
Table 2: The results of experimental finding in patients in baseline.

\begin{tabular}{|c|c|c|c|c|}
\hline Variables & & Case & Control & $\begin{array}{l}\text { p- } \\
\text { value }\end{array}$ \\
\hline \multirow{2}{*}{$\mathrm{Hb}$} & Case & $10 / 78$ & $1 / 92$ & \multirow{2}{*}{$0 / 558$} \\
\hline & Control & $11 / 03$ & $1 / 71$ & \\
\hline \multirow{2}{*}{ Hematocrit } & Case & $30 / 80$ & $5 / 98$ & \multirow{2}{*}{$0 / 444$} \\
\hline & Control & $31 / 86$ & $5 / 50$ & \\
\hline \multirow{2}{*}{ Platelet } & Case & 315000 & 95000 & \multirow{2}{*}{$0 / 318$} \\
\hline & Control & 285000 & 84000 & \\
\hline \multirow{2}{*}{ Iron } & Case & $52 / 3$ & $32 / 5$ & \multirow{2}{*}{$0 / 337$} \\
\hline & Control & $48 / 7$ & $28 / 5$ & \\
\hline \multirow{2}{*}{ Ferritin } & Case & $668 / 5$ & $317 / 5$ & \multirow{2}{*}{$0 / 290$} \\
\hline & Control & $721 / 4$ & $468 / 7$ & \\
\hline \multirow{2}{*}{ BUN } & Case & $66 / 65$ & $43 / 04$ & \multirow{2}{*}{$0 / 853$} \\
\hline & Control & $68 / 5$ & $41 / 6$ & \\
\hline \multirow{2}{*}{$\mathrm{Cr}$} & Case & $1 / 54$ & $1 / 12$ & \multirow{2}{*}{$0 / 834$} \\
\hline & Control & $1 / 62$ & $1 / 16$ & \\
\hline
\end{tabular}

The results showed that, there was no significant increase in hemoglobin and Hematocrit levels after receiving erythropoietin in the case group compare to control group (Table 3). Hemoglobin levels in the case group at the end of the study was significantly higher than the baseline but in the Hematocrit level the difference wasn't significant (Table 4).

Table 3: Hb and Hematocrit of patients after drug receiving.

\begin{tabular}{|lllll|}
\hline Variables & & Case & Control & $\begin{array}{l}\text { p- } \\
\text { value }\end{array}$ \\
\hline \multirow{2}{*}{$\mathrm{Hb}$} & Case & $11 / 95$ & $1 / 50$ & \multirow{2}{*}{$0 / 105$} \\
\cline { 2 - 4 } & Control & $11 / 40$ & $1 / 26$ & \\
\hline \multirow{2}{*}{ Hematocrit } & Case & $35 / 07$ & $4 / 54$ & \multirow{2}{*}{$0 / 074$} \\
\cline { 2 - 4 } & Control & $33 / 25$ & $3 / 79$ & \\
\hline
\end{tabular}

Table 4: Compare the $\mathrm{Hb}$ of patients in two groups in the end of study compare to base line.

\begin{tabular}{|c|c|c|c|c|}
\hline Variable & & Case & Control & p-value \\
\hline \multirow[b]{2}{*}{ Case } & Baseline & $10 / 78$ & $1 / 92$ & \multirow[b]{2}{*}{$0 / 006$} \\
\hline & $\begin{array}{l}\text { End of } \\
\text { study }\end{array}$ & $11 / 95$ & $1 / 50$ & \\
\hline \multirow[b]{2}{*}{ Control } & Baseline & $11 / 03$ & $1 / 71$ & \multirow[b]{2}{*}{$0 / 307$} \\
\hline & $\begin{array}{l}\text { End of } \\
\text { study }\end{array}$ & $11 / 40$ & $1 / 26$ & \\
\hline
\end{tabular}

\section{DISCUSSION}

Anemia is a common problem in ICU patients who increase their illness and mortality. ${ }^{2}$ In this study, the mean of hospital stay was 37.73 days in ICU and 21.35 days in surgery ICU. Also, it was observed that hemoglobin level in internal patients at the beginning of the study was lower than surgical patients $(\mathrm{P}=0.023)$ and the increase in hemoglobin level in internal patients was significantly higher than patients undergoing surgery $(\mathrm{P}=0.001)$. In a study by Corwin et al 16 there was no significant correlation between the duration of hospitalization in ICU between traumatic and non traumatic patients after receiving erythropoietin $(\mathrm{P}=0.43)$. In Georgopoulos et al study ${ }^{13}$, the duration of hospitalization in ICU in the control group was 21.8 days and, in the group, receiving erythropoietin (once daily) was 21 days and in the recipient of erythropoietin (three times a day) was 19.6 days but this difference wasn't significant. In the study of van Iperen and et al, the mean duration of hospitalization in ICU was 37 days in erythropoietin recipients and 58 days in placebo and this difference was statistically significant $(\mathrm{P}=0.03){ }^{6}$

In this study, $80 \%$ of patients in the case group and $88.57 \%$ in the control group needed to blood transfusion. The mean of need for transfusion in case group was 5.8 \pm 1.8 and in the control group was $3.6 \pm 2.9$ and it was found that erythropoietin could not reduce the number of recipients and the number of $\mathrm{P} / \mathrm{C}$ units. Studies done elsewhere is in line with the study results. ${ }^{6,17,18}$ There were also conflicting studies with our study and had adverse results. ${ }^{13,19,20}$

The reason for the lack of correlation between the numbers of transfusions with erythropoietin injection in this study can be due to: 1) transfusion at higher levels of hemoglobin 2) the most common cause of bleeding and acute anemia among patients and other factors.

In this study, $68.6 \%$ of patients in the case group and $71.4 \%$ of the patients in the control group survived to the end of the study and discharge from the ICU and there was no difference in the prognosis of the disease between the two groups. The present study showed that there is no correlation between the prognosis of patients admitted to ICU and erythropoietin administration which in line with our study results. ${ }^{12-14,19,20}$

A number of studies have also shown that injectable erythropoietin could improve the prognosis of patients. ${ }^{19,21}$ In the following study the prognosis of patients was different for different reasons and authors can't said that erythropoietin can interfere with patient's prognosis which most studies have confirmed.

In this study, there was no significant difference in the level of hemoglobin between two groups at the time of admission and at the end of the study. It was observed that hemoglobin level was significantly increased in the erythropoietin recipient group $(\mathrm{P}=0.006)$ that this increase wasn't observed in the control group. The results of this study are in line with other studies ${ }^{12-14,17,19,21}$

In this study, no significant difference was found between the hemoglobin in the case and control groups which can be related to the more transfusion in these patients but in summary erythropoietin could be increase hemoglobin levels in recipients. 


\section{CONCLUSION}

The results of this study showed that erythropoietin is effective drug for increasing hemoglobin levels and can increase the hemoglobin level in compare to the placebo.

It is suggested that another study has been done to evaluate the level of hemoglobin in patients with chronic underlying illness in the future in a larger population.

\section{ACKNOWLEDGEMENTS}

Authors would like to thanks Dr. Asghar Pirzadeh for helping in the sampling and designing the research proposal and also collecting the data. Also authors want to thanks all patients and their relatives which participated in the study.

\section{Funding: No funding sources}

Conflict of interest: None declared

Ethical approval: The study was approved by the Institutional Ethics Committee

\section{REFERENCES}

1. Blinder RM. Anemia and Transfusion therapy. In: Foster C, Mistry NF, Peddi PF, Sharma S. The Washington manual of medical therapeutics. $33^{\text {rd }}$ Edition. Wolters kluwer/Lippincott Williams and Wilkins; 2010:713-747.

2. Prakash D. Anemia in the ICU: Anemia of chronic disease versus anemia of acute illness. Crit Care Clin. 2012;28(7):333-43.

3. Roberts DJ, Zygun DA. Anemia, red blood cell transfusion, and outcomes after sever traumatic brain injury. Crit Care. 2012;16(5):154.

4. Rodriguez RM, Corwin HL, Gettinger A, Corwin MJ, Gubler D, Pearl RG. Nutritional deficiencies and blunted erythropoietin response as causes of the anemia of critical illness. J Crit Care. 2001;16:36-41.

5. Corwin HL, Gettinger A, Pearl RG, Fink MP, Levy AM, Abraham E, et al. The CRIT study: Anemia and blood transfusion in the critically ill: current clinical practice in the United States. Crit Care Med. 2004;32:39-52.

6. Van Iperen CE, Gaillard CM, Kraaijenhagen RJ, Braam BG, Marx JM, van de Wiel A. Response of erythropoiesis and iron metabolism to recombinant human erythropoietin in intensive care unit patients. Crit Care Med. 2000;28:2773-8.

7. Hebert PC, Wells G, Blajchman MA, Marshall J, Martin C, Pagliarello G, et al. A multicenter, randomized, controlled clinical trial of transfusion requirements in critical care. Transfusion Requirements in Critical Care Investigators, Canadian Critical Care Trials Group. N Engl J Med. 1999;340:409-17.
8. Kopko PM. transfusion-related acute lung injury: pathophysiology, laboratory investigation, and donor management. Immunohematol. 2004;20:103-11.

9. MacLennan S, Williamson LM. Risks of fresh frozen plasma and platelets. J Trauma. 2006;60:S46-S50.

10. Volar AP, Maur AL, Binnekade JM, Schultz MJ, Juffermans NP. Determinants of transfusion decisions in a mixed medical-surgical intensive care unit: a prospective cohort study. Blood Transfus. 2009 Apr;7(2):106-10.

11. Gould S, Cimino MJ, Gerber DR. Packed red blood cell transfusion in the intensive care unit: limitations and consequences. Am J Crit Care. 2007;16(1):39-48.

12. Corwin HL, Gettinger A, Pearl RG, Fink MP, Levy MM, Shapiro MJ. Efficacy of recombinant human erythropoietin in critically ill patients: a randomized controlled trial. JAMA. 2002;288:2827-35.

13. Georgopoulos D, Matamis D, Routsi C. Recombinant human erythropoietin therapy in critically ill patients: a dose-response study. Crit Care. 2005;9:R508-15.

14. Corwin H, Gettinger A. Efficacy of recombinant human erythropoietin in the critically ill patient: A randomized, double-blind, placebo-controlled trial. Crit Care. 2001;29:R518-12.

15. Fauci AS, Braunwald E. Harrison principles of internal medicin, $18^{\text {th }}$ Ed, new york. MC Graw-hill; 2012.

16. Corwin HL, Gettinger A, Fabian TC, May A, Pearl RG, Heard S. Efficacy and safety of epoetin alfa in critically ill patients. N Engl J Med. 2007;357:965-76.

17. Shapiro MJ, Gettinger A, Corwin HL, Napolitano L, Levy M, Abraham E. Anemia and blood transfusion in trauma patients admitted to the intensive care unit. $\mathbf{J}$ Trauma. 2003;55:269-73.

18. Hecht D, Boujoukos A. Anemia in the ICU: are your patients needing erythropoetin? Critical Care. 2010;14:332.

19. Corwin HL, Gettinger A, Rodriguez RM, Pearl RG, Gubler KD, Enny C. Efficacy of recombinant human erythropoietin in the critically ill patient: a randomized, double-blind, placebo-controlled trial. Crit Care Med. 1999;27:2346-50.

20. Silver M, Corwin MJ, Bazan A, Gettinger A, Enny C, Corwin HL. Efficacy of recombinant human erythropoietin in critically ill patients admitted to a long-term acute care facility: a randomized, doubleblind, placebo-controlled trial. Crit Care Med. 2006 Sep;34(9):2310-6.

21. Napolitano LM, Fabian TC, Kelly KM, Bailey JA, Block EF, Langholff W. Improved survival of critically ill trauma patients treated with recombinant human erythropoietin. J Trauma. 2008;65:285-97.

Cite this article as: Feizi I, Norouzi V. Efficacy of Erythropoietin in treatment of anemia in patients hospitalized in the ICU of Ardabil city hospital. Int $\mathbf{J}$ Basic Clin Pharmacol 2018;7:1674-7. 